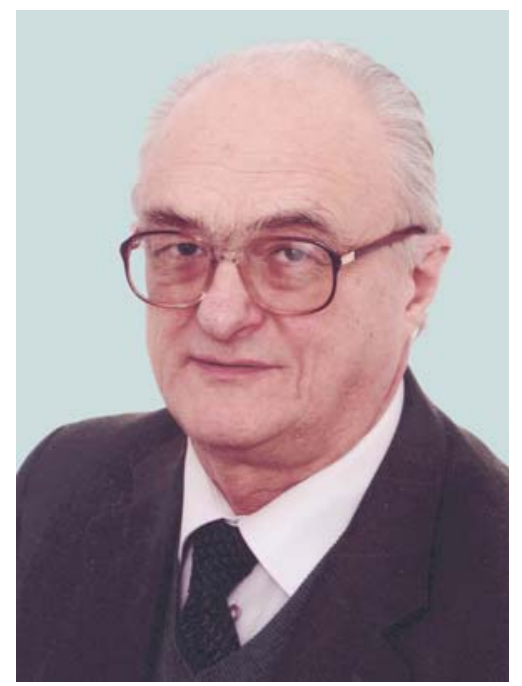

ШЕСТОПАЛОВ

Вячеслав Михайлович академік НАН України, директор Державної установи «Науково-інженерний центр радіогідрогеоекологічних полігонних досліджень НАН України»

\section{СТВОРЕННЯ ГЕОЛОГІЧНОГО СХОВИЩА РАДІОАКТИВНИХ ВІДХОДІВ - НАЙВАЖЛИВІШЕ ЗАВДАННЯ ЩОДО ЛІКВІДАЦІї НАСЛІДКІВ ЧОРНОБИЛЬСЬКОЇ ABAPIÏ}

\author{
Стенограма доповіді на засіданні \\ Президії НАН України 28 квітня 2021 року
}

У доповіді розглянуто сучасний стан наукового обгрунтування створення геологічного сховища радіоактивних відходів в Украйні та наведено останні результати проведених науково-дослідних робіт з визначення перспективних площ, у кристалічних породах Чорнобильської зони відчуження і на прилеглих територіях. Проаналізовано міжнародний досвід спорудження глибинних геологічних сховищ радіоактивних відходів. Обговорено потенційні ризики від зволікання з проведенням робіт з вибору майданчика для розміщення геологічного сховища радіоактивних відходів.

Шановний Анатолію Глібовичу!

Шановні члени Президії! Шановні колеги!

Як ви всі знаєте, в результаті Чорнобильської аварії утворилися величезні обсяги радіоактивних відходів (РАВ). Крім того, виробництво електроенергії на АЕС супроводжується постійним накопиченням певної кількості відпрацьованого ядерного палива, в процесі перероблення якого утворюються високоактивні РАВ, що містять значну кількість довгоіснуючих радіонуклідів і залишаються небезпечними від десятків до сотень тисяч років.

Зараз на території України накопичено 3,5 млн м ${ }^{3}$ РАВ - це відпрацьоване ядерне паливо українських АЕС, відходи переробки уранових руд, використання радіоактивних ізотопів у медицині, військовій справі, науковій діяльності та ін. Проте левову їх частку (понад 95\%, або 3,3 млн м ${ }^{3}$ ) становлять РАВ аварійного походження, зосереджені в Чорнобильській зоні відчуження. У Зоні також накопичилися радіоактивно забруднені матеріали (деревина, грунт, будівельні конструкції тощо) загальним обсягом близько 11 млн м 
При цьому 97 \% РАВ в Україні є короткоіснуючими, тобто їх можна зберігати в поверхневих сховищах, але $3 \%$ - це середньо- та високоактивні РАВ, які слід ізолювати в так званих глибинних геологічних сховищах, і це є необхідною умовою подальшого ефективного функціонування ядерної енергетики України. Слід також зазначити, що понад 90 \% таких високоактивних довгоіснуючих РАВ знаходиться у Чорнобильській зоні відчуження.

Отже, єдиним на сьогодні, безальтернативним, економічно виправданим, технічно досяжним, суспільно і соціально прийнятним способом безпечного поводження з високоактивними і довгоіснуючими радіоактивними відходами є ïх захоронення в геологічному сховищі.

Науково-інженерний центр радіогідрогеоекологічних полігонних досліджень НАН України брав активну участь у розробленні нової системи класифікації РАВ за можливістю їх захоронення. Ця класифікація набуває чинності в Україні з листопада 2021 р. На відміну від попередньої класифікації, в якій було передбачено захоронення РАВ у двох видах сховищ - поверхневих та глибинних, у новій системі класифікації на законодавчому рівні закріплено можливість ізоляції РАВ у чотирьох видах сховищ, а саме:

1) для захоронення дуже низькоактивних відходів (ДНАВ), які становлять 50-70\% нинішніх обсягів короткоіснуючих РАВ і можуть бути позбавлені контролю через 70-100 років, використовують сховища типу 1 - на зразок полігонів побутових відходів (наприклад, пункт захоронення радіоактивних відходів (ПЗРВ) «Буряківка»);

2) для захоронення низькоактивних відходів (НАВ) - частини нинішніх обсягів короткоіснуючих РАВ та певної частини середньоактивних, які можуть бути позбавлені контролю через 300 років, використовують сховища типу 2 - поверхневі сховища (наприклад, сховища комплексу «Вектор»);

3) для захоронення середньоактивних відходів (САВ), що відповідають нинішнім довгоіснуючим РАВ, використовують сховища типу 3 - сховища на проміжній глибині

\section{8}

(як приклад можна навести сховище SFR y Швеції);

4) для захоронення високоактивних відходів (BAB), що становлять малу частину нинішніх довгоіснуючих РАВ, використовують сховища типу 4 - глибинні геологічні сховища, які можуть бути шахтного або свердловинного виду.

Запровадження нової класифікації РАВ дає значний економічний ефект. Так, при використанні двох типів сховищ (поки що чинна класифікація) реалізація програми із захоронення РАВ коштувала б Україні у цінах 2012 р. 75 млрд дол. США, а за нової системи класифікації ця сума зменшується у 40 разів - до 1,8 млрд дол. США.

Безальтернативність створення геологічного сховища в Україні та необхідність змінення державної політики поводження 3 РАВ підтверджується також тим, що нинішня практика, коли Україна переробляє і зберігає відпрацьоване ядерне паливо своїх АЕС у Російській Федерації, коштує нашій державі 150-200 млн дол. США щороку, тобто за 30 років незалежності ми вже витратили понад 5 млрд дол. США. I якщо не буде прийнято відповідні рішення, такі виплати продовжуватимуться й надалі.

Актуальність створення в Україні геологічного сховища визначається серед іншого й тим, що країни, які використовують ядерну енергію і мають наміри вступити в Свросоюз, повинні впровадити власні комплексні програми захоронення РАВ у геологічних сховищах. Світовий досвід свідчить, що геологічні сховища, призначені для ізоляції найбільш небезпечних PAB, на сьогодні є єдиним економічно виправданим і коректним щодо прийдешніх поколінь варіантом їх безпечного зберігання.

Вибір і дослідження місця для розташування геологічного сховища є одним 3 найскладніших комплексних та інноваційних завдань у геології, вирішення якого потребує кількох десятків років і передбачає залучення фахівців 3 різних дисциплін. Це завдання набагато складніше порівняно 3 традиційним геологічним картуванням чи пошуком будь-яких родовищ корисних копалин.

ISSN 1027-3239. Visn. Nac. Acad. Nauk Ukr. 2021. (7) 
Прикладом позитивного вирішення зазначеної проблеми є досвід Фінляндії, яка, маючи лише дві АЕС встановленою потужністю 5,6 ГВт, вже побудувала геологічне сховище об'єкт Онкало і в 2023 р. має розмістити в ньому перші контейнери з відпрацьованим ядерним паливом. Швеція планує вже в 2025 р. ввести в експлуатацію геологічне сховище, розташоване поблизу м. Форсмарк. У Франції реалізується проєкт будівництва глибинного сховища CIGEO. Досвід цих країн свідчить, що процес обгрунтування і проведення польових геологічних робіт з вибору майданчика для розміщення сховища потребує потужного наукового супроводу і тривалого часу - близько 40 років.

Наукові дослідження 3 пошуку місця для створення геологічного сховища в Україні проводяться починаючи з 1993 р., і на сьогодні ми вже маємо конкретні науково обгрунтовані висновки 3 цього питання. При цьому ми використовували загальноприйнятий у світі підхід, за яким геологічні умови майбутнього майданчика мають бути не найкращими, а такими, які здатні забезпечити достатній рівень безпеки зберігання РАВ з урахуванням комплексу економічних, демографічних, соціальних та багатьох інших факторів.

Співробітники Науково-інженерного центру радіогідрогеоекологічних полігонних досліджень НАН України разом із фахівцями інших профільних організацій провели регіональний скринінг території України з метою вибору одного регіону, в якому можливе створення геологічного сховища, для подальшого здійснення в ньому локального скринінгу.

Методологія проведення регіонального скринінгу передбачає виконання чотирьох процедур, які відповідають міжнародним вимогам: 1) вилучення 3 подальшого розгляду регіонів, непридатних для спорудження геологічного сховища; 2) кваліфікація для подальшої оцінки лише регіонів з прийнятними умовами; 3) ранжування - визначення відносної перспективності регіонів, у яких є всі умови для безпечного геологічного захоронення РАВ; 4) проведення соціально-економічної оцінки вибору об'єкта для локального скринінгу.
У результаті було зроблено висновок, що найбільш перспективним регіоном України для створення глибинного геологічного сховища слід вважати Чорнобильську зону відчуження з прилеглими до неї територіями, а найбільш прийнятною концепцією - захоронення РАВ у кристалічних породах.

На сьогодні у Чорнобильській зоні відчуження та на прилеглих територіях (загальною площею 9 тис. км ${ }^{2}$ ) виконано більшу частину запланованих робіт з проведення локального скринінгу, які здійснювали за допомогою космічної та аерозйомки, а також з використанням геофізичних (сейсмо- і магніторозвідка, гравіметрія, петрофізичні методи), геологічних (зокрема, дані картувального буріння), гідрогеологічних методів досліджень. Основними критеріями для пошуку потенційного місця розташування майданчика були наявність малоградієнтних геофізичних полів, розташування поза великими розломними зонами, на площах 3 низькою щільністю лінеаментів, на вододілах рельєфу та з урахуванням трансграничних обмежень.

У результаті виконання локального скринінгу ми виокремили три перспективні площі (див. рис.) для проведення пошуково-розвідувальних робіт - Новосілки (площа -400 км² $^{2}$ осадова товща - 350-500 м), Вересня (пло-

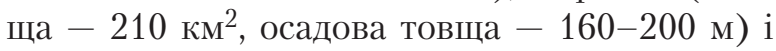
Жовтневе (площа -80 км² $^{2}$ осадова товща 50-100 м). Причому Вересня розташована поруч з Чорнобильською зоною відчуження і є резервною для досліджень. Усі ці ділянки відповідають зазначеним вище критеріям: характеризуються низькими градієнтами геофізичних полів, мають мінімальну щільність розвитку тріщинуватості, розташовані поза розломними зонами, на вододілах за межами заплав основних річкових систем.

Слід зазначити, що за результатами проведених досліджень нам вдалося знайти значно кращі, ніж у Швеції, Фінляндії та Франції, перспективні території для створення глибинного геологічного сховища. Це пояснюється тим, що в Чорнобильській зоні відчуження граніти і гнейси кристалічних порід перекриті 


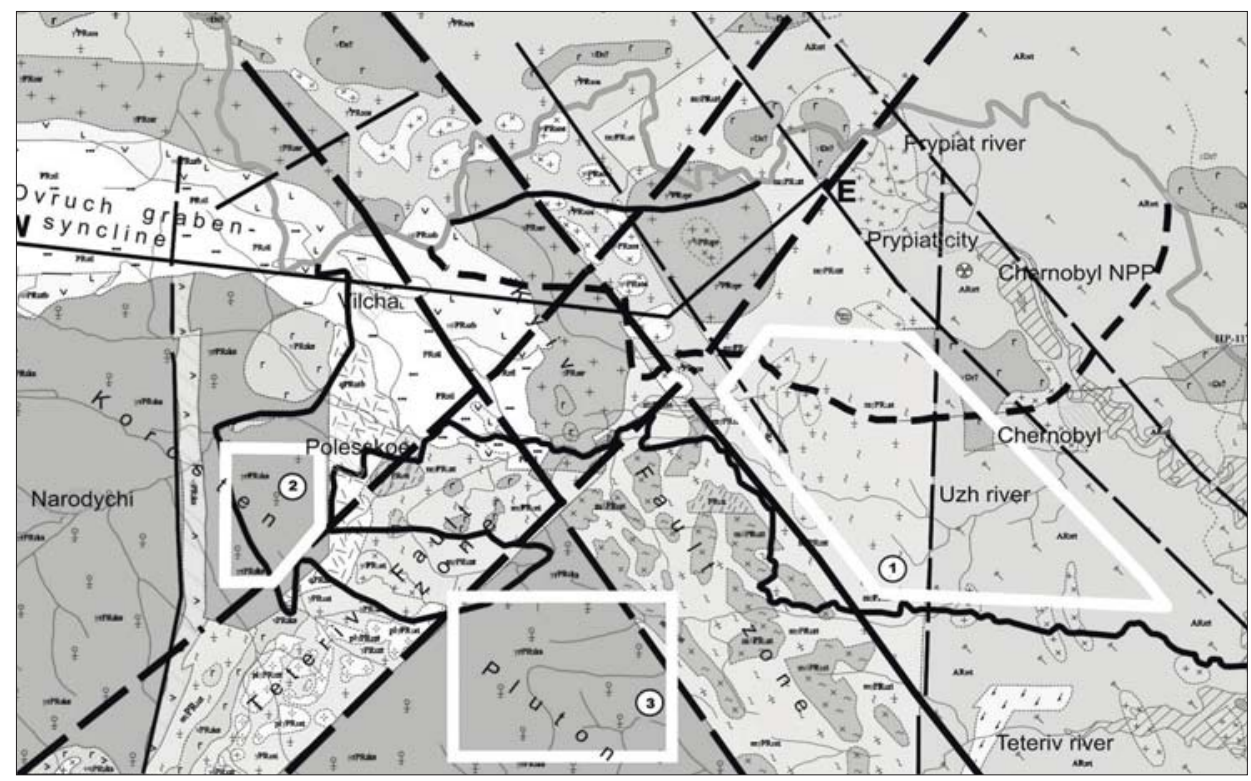

Схема розташування перспективних площ для подальших робіт 3 визначення майданчиків для глибинного геологічного сховища в Чорнобильській зоні відчуження: 1 Новосілки; 2 - Жовтневе; 3 - Вересня осадовим чохлом, який має дуже високу сорбційну здатність. Наявність осадових порід дає унікальний, порівняно з аналогічними майданчиками в інших країнах, ступінь захисту, що сприяє зниженню концентрації радіонуклідів у підземних водах унаслідок їх розбавлення і адсорбування в осадовому чохлі, сповільненню деградації інженерних бар'єрів через зменшення потоку підземних вод, послабленню впливу можливого в майбутньому зледеніння. Причому це дозволяє значно зменшити кошторис на будівництво сховища, оскільки технічні бар'єри можуть бути не такими потужними, як у Фінляндії чи Швеції.

Отже, актуальність питання щодо створення в Україні геологічного сховища РАВ з кожним роком зростає. По-перше, спорудження глибинного геологічного сховища забезпечить подальший стійкий розвиток вітчизняної ядерної енергетики. По-друге, без такого сховища не можна завершити процес ліквідації наслідків Чорнобильської катастрофи. По-третє, як я вже говорив, це економічно доцільно з огляду на нинішню практику переробки в РФ відпрацьованого ядерного палива українських АЕC. По-четверте, країни, які використовують ядерну енергію і мають наміри інтегруватися в $\mathrm{CB}_{\text {в- }}$ росоюз, згідно з директивою Свратому, повин- ні мати відповідну національну політику поводження з відпрацьованим ядерним паливом і РАВ та впроваджувати власні комплексні програми їх захоронення у геологічних сховищах.

Постійне відтермінування в нашій країні проведення пошуково-розвідувальних і науково-дослідних робіт, передбачених Державною програмою та Стратегією поводження 3 радіоактивними відходами, які за розділом щодо створення геологічного сховища РАВ традиційно не фінансуються, призводить до цілої низки інших, крім зазначених вище, негативних наслідків. Зокрема, Україна стрімко втрачає власну школу кваліфікованих геологів - розвідників надр. В Академії і Державній геологічній службі, яка вже значною мірою зруйнована, поступово звільняються за віком i через скорочення геологи, геофізики, буровики та інші фахівці, спроможні грамотно виконувати необхідний цикл робіт. Поступово переривається естафета 3 передання знань i вмінь від досвідчених фахівців молодим спеціалістам, що зрештою може призвести до повної неспроможності виконання власними силами геологорозвідувальних робіт на належному сучасному рівні. 3 часом також виходить з ладу обладнання, що в майбутньому потребуватиме залучення зарубіжних фахівців та придбання

ISSN 1027-3239. Visn. Nac. Acad. Nauk Ukr. 2021. (7) 
чи оренди відповідних технічних засобів іноземного виробництва, що спричинить істотне подорожчання робіт.

Своєрідним «символом» руйнації стратегічно важливих геологічних колективів є намагання ліквідувати Український державний геологорозвідувальний інститут (УкрДГРІ), зокрема звільнити в повному складі Чернігівський відділ методики нафтогазопошукових робіт на чолі з видатним геологом академіком НАН України О.Ю. Лукіним, хоча серед здобутків цього колективу - відкриття 120 родовищ нафти і газу, прогнозування нових родовищ, напрацювання разом з фахівцями академічних установ методології пошуків родовищ водню, методів захоронення парникових газів тощо. Ліквідація такого потужного колективу - це, по суті, руйнівний удар по високопрофесійній еліті країни, подарунок ворогам України і пряма загроза економічній безпеці держави в майбутньому. I це не єдиний приклад, адже приватизація матеріальних активів часто супроводжується знищенням професійних колективів, що сповільнює подальший економічний розвиток.

Крім того, непослідовність державної політики стосовно призначення Чорнобильської зони відчуження призводить до численних проблем. Так, змінення цільового призначення земель на території Зони і віднесення їх до природно-заповідного фонду значно ускладнить проведення польових робіт та розміщення глибинного геологічного сховища РАВ. Проте, як я вже казав, оптимальною територією для спорудження такого сховища є саме Чорнобильська зона, адже створення сховища в іншому місці спричинить соціальне напруження у вибраному регіоні, призведе до значного підвищення вартості геологічного захоронення та збільшення витрат на транспортування радіоактивних відходів, оскільки $90 \%$ РАВ, що підлягають глибинному захороненню, зосереджено на території Зони відчуження.

Змінення цільового призначення земель на території Чорнобильської зони відчуження зумовлює й інші загрози. Зокрема, віднесення цих земель до заповідного фонду значно ускладнить проведення там обов'язкових лісоі гідротехнічних заходів, що спричинить зростання ризиків розвитку надзвичайної радіаційної ситуації, зменшить бар'єрні функції лісу та гідротехнічних споруд, утруднить вжиття заходів швидкого реагування в разі пожежі. Причому ці загрози з часом лише зростатимуть у зв’язку зі змінами клімату. Так, у 2015 р. площа лісових пожеж у Чорнобильській зоні становила 17 км² $^{2}$ виносом 130 ГБк цезію-137. У 2020 р. площа пожежі становила вже 680 км ${ }^{2}$ (це приблизно 25\% території Зони) з виносом 700 ГБк цезію-137. Нагадаю, що відповідно до норм радіаційної безпеки - НРБУ-97 радіаційні наслідки пожежі 2020 р. класифікуються як глобальна комунальна аварія. При цьому утворився субстрат для нових, ще потужніших пожеж.

Тому ця ситуація терміново потребує законодавчого врегулювання. Вже найближчим часом необхідно усунути суперечності, які виникають між дією Закону України про Чорнобильську зону відчуження та Указом Президента України про створення Чорнобильського радіаційно-екологічного біосферного заповідника, віддавши пріоритет закону.

Дякую за увагу!

За матеріалами засідання підготувала О.О. Мележик 
Vyacheslav M. Shestopalov

Radio-Environmental Center of the National Academy of Sciences of Ukraine, Kyiv, Ukraine

CREATION OF A GEOLOGICAL REPOSITORY FOR RADIOACTIVE WASTE IS THE MOST IMPORTANT TASK IN DEALING WITH THE CONSEQUENCES OF THE CHERNOBYL DISASTER

Transcript of the report at the meeting of the Presidium of NAS of Ukraine, April 28, 2021

The report considers the current state of scientific substantiation of the creation of a geological repository of radioactive waste in Ukraine and presents the latest results of research work to determine promising areas in crystalline rocks of the Chernobyl Exclusion Zone and adjacent territories. The international experience of construction of deep geological repositories of radioactive waste is analyzed. The potential risks of delay in selecting a site for the placement of deep geological repository of radioactive waste are discussed.

Keywords: radioactive waste, deep geological repository, waste disposal. 